\title{
Development and Assessment of New RT-qPCR Assay for Detection of HIV-1 Subtypes
}

\author{
Kwanhun Lim ${ }^{1}$, Min Park ${ }^{3}$, Min Ho Lee², Hyun Jun Woo² and Jong-Bae Kim, ${ }^{2, \dagger}$ \\ ${ }^{1}$ Bioneer Corporation, 8-11 Munpyengseoro, Daedeok-gu, Daejeon 34302, Korea \\ ${ }^{2}$ Department of Biomedical Laboratory Science, College of Health Sciences, Yonsei University, \\ Wonju-si, Gangwon-do 26493, Korea \\ ${ }^{3}$ Department of Clinical Laboratory Science, Hyejeon College, Hongseoung, \\ Chungcheong Nam-do 32244, Korea
}

The measurement of viral load in HIV-1 infected patients is essential for the establishment of a therapeutic strategy. Several commercial assays have shown shortcomings in quantifying rare genotypes of HIV-1 such as minor groups of $\mathrm{N}$ and O. In this study, the HIV-1 RT-qPCR assay was developed. The primers and probe of HIV-1 were designed to target the pol gene and to increase the detection efficiency of various subtypes including group $\mathrm{N}$ and $\mathrm{O}$. The HIV-1 quantitative RT-qPCR assay was assessed for its analytical performance and clinical evaluation. The LoD was determined to $33.9 \mathrm{IU} /$ $\mathrm{ml}$. The LoD of several subtypes including A, C, D, CRF_01AE, F, CRF_02AG, G and H, were determined to less than $40 \mathrm{IU} / \mathrm{ml}$. The HIV-1 quantitative RT-qPCR assay was evaluated using the China National Reference Panel of HIV-1 RNA to determine the analytical performance. The results were all within the acceptable range. The clinical evaluation was performed at Hunan CDC in China. The clinical evaluation results were compared with those of the China domestic commercial kit. A significant correlation (fresh samples; $\mathrm{R}^{2}=0.84, P<0.001$, frozen samples; $\mathrm{R}^{2}=0.76, P<0.001$ ) between the two systems was observed for 64 fresh samples and 76 frozen samples with viral loads, and the Bland-Altman plot showed good agreement $(98.4 \%, 96.1 \%$, respectively). In conclusion, the HIV-1 quantitative RT-qPCR assay had comparable analytical performance with several commercial kits. The study provides basic data for the research of HIV-1 diagnosis and the development of $P<\mathrm{HIV}-1$ molecular diagnostic assay.

Key Words: HIV-1, RT-qPCR, Viral load measurement

\section{INTRODUCTION}

The human immunodeficiency virus (HIV) is a member of the Lentivirus genus, which is a part of the Retroviridae family (Weiss, 1993; Moss, 2013). HIV consists of HIV type 1 (HIV-1) and HIV type 2 (HIV-2) that have been shown to cause acquired immune deficiency syndrome (AIDS). While both of these have similar modes of transmission, it is now well recognized that the in vivo pathogenicity of HIV-2 is attenuated relative to that of HIV-1, with significantly lower rates of disease progression and transmission (Marlink et al., 1988; Marlink et al., 1994; Reeves and Doms, 2002; MacNeil et al., 2007). HIV-1 is highly diverse, consisting of three major groups (major [M], outlier [O], and nonmajor and nonoutlier $[\mathrm{N}]$ ) and a new minor group, $\mathrm{P}$, which was

\footnotetext{
* Received: July 18, 2016 / Revised: July 27, 2016 / Accepted: July 29, 2016

${ }^{\dagger}$ Corresponding author: Jong-Bae Kim. Department of Biomedical Laboratory Science, College of Health Sciences, Yonsei University, Wonju-si, Gangwon-do, 26493, Korea.

Tel: +82-33-760-2423, Fax:+82-33-760-2561, e-mail: kimjb70@yonsei.ac.kr

(C) The Korean Society for Biomedical Laboratory Sciences. All rights reserved.

(c) This is an Open Access article distributed under the terms of the Creative Commons Attribution Non-Commercial License (http://creativecommons.org/licenses/by-nc/3.0/) which permits unrestricted non-commercial use, distribution, and reproduction in any medium, provided the original work is properly cited.
} 
first reported in 2009. The $\mathrm{M}$ group has been reported to have various subtypes (A, B, C, D, F, G, H, J, and K; only for group M), several sub-subtypes (A1, A2, A3, A4, F1, and F2), and 66 CRFs (Los Alamos HIV Database, http:// www.hiv.lanl.gov/content/sequence/HIV/CRFs/CRFs.html) resulting from the recombination of different subtypes or strains (Hemelaar et al., 2006; Lees et al., 2006; Taylor and Hammer, 2008; Plantier et al., 2009).

The global distribution of HIV-1 subtypes is diverse. The predominant HIV-1 genotypes are subtypes C (47\%), A (27.2\%), B (12.3\%), D (5.3\%), and CRF01_AE (3.2\%) (Osmanov et al., 2002; Takebe et al., 2004; Buonaguro et al., 2007; Abecasis et al., 2013). In Korea, the predominant HIV-1 genotypes are subtypes B (81.5\%), A (7.7\%), AE (6.5\%), and G (2.6\%) (Korea CDC, 2008).

Viral load is the most important indicator of initial and sustained response to antiretroviral therapy (ART) at the initiation of therapy and on a regular basis thereafter. Several systematic reviews of data from clinical evaluations involving thousands of participants have established that decreases in viral load following the initiation of ART are associated with a reduced risk of progression to AIDS or death. Thus, viral load testing is an established surrogate marker for treatment response (AIDSinfo, 2014). Significant virus under-quantification has the potential to lead to an inappropriate strategy for patient management (Geelen et al., 2003). In particular, the genetic heterogeneity of HIV-1 is an important factor with the potential to jeopardize the reliability of viral load measurements (Holguin et al., 1999; Michael et al., 1999; Triques et al., 1999; Clarke et al., 2000; Jagodzinski et al., 2000; Swanson et al., 2000; Amendola et al., 2002; Mendoza et al., 2002).

All nucleic acid amplification technologies rely on HIV-1 sequence-specific primers and/or probes. Natural polymorphisms occurring in these target regions have the potential to reduce or abolish hybridization, thus compromising the reliability of quantification. In most cases, subtypes and target sequence information are unknown at the time of viral load assessment, so genetically divergent variants go unrecognized. For this reason, viral load tests should be able to detect and quantify the various subtypes (Amendola et al., 2014).

Current international guidelines and clinical evaluation define virological suppression as the achievement and the maintenance of HIV-1 RNA levels less than 50 copies/ml or to levels below assay limits as the virologic endpoint of successful ART. In contrast, the HIV RNA threshold for defining virological failure differs from guidelines. In fact, the WHO guideline defines virological failure as a viral load that is persistently more than 1,000 copies/ml after 6 month of using ART. Instead, the British HIV Association (BHIVA), International Antiviral Society (IAS), European AIDS Clinical Society (EACS), and Department of Health and Human Services (DHHS) guidelines consider virological failure to be a viral load of more than $400,200,50$, or 48 copies/ml after suppression, respectively (Amendola et al., 2014).

Several commercial assays based on real-time PCR are composed of nucleic acid extraction part and real-time PCR part. Currently, many manufacturers provide the automated nucleic acid extraction system in order to increase accuracy of quantification of viral load and reduce operator error and laboratory contamination. Even though commercial assays have different sample volume, applied system, target gene, sensitivity and dynamic range, all commercial assays meet the requirement of various performance indexes. Therefore, the new assay of quantification of HIV-1 viral load should have comparable performance with other commercial assay and meet the various guideline of ART.

The aim of this study was to develop and assess the HIV-1 quantitative RT-qPCR assay. The primers and probe for the assay were designed to target the pol gene of HIV-1 and to increase the detection efficiency of various subtypes, including groups $\mathrm{M}, \mathrm{N}$, and $\mathrm{O}$. To determine the analytical performance of developed assay, LoD, subtypes LoD, dynamic range, precision, cross-reactivity, and interfering substances testing were tested with a reference material or HIV-1 positive control materials. The clinical performance of the HIV-1 quantitative RT-qPCR assay was evaluated using 163 EDTA-plasma clinical samples in China.

\section{MATERIALS AND METHODS}

\section{HIV-1 positive control particle}

Turnip yellow mosaic virus (TYMV) is a positive-strand 
RNA virus. In this study, a part of HIV-1 pol gene was inserted into the TYMV genome for using calibration of the HIV-1 quantitative assay. The genome construction and several analyses of HIV-1 positive control particle were conducted according to the procedure of Shin et al. (Shin et al., 2008). The nucleic acid of the HIV-1 positive control particle was extracted using an ExiPrep ${ }^{\mathrm{TM}}$ Dx Viral RNA kit (Bioneer, Daejeon, Korea), and the concentration and purity of the RNA was measured using NanoDrop 2000 (Thermo Fisher Scientific, Waltham, USA).

\section{Oligomer design}

The HIV-1 genome sequence alignment was set up to include all subtype information presented in the Los Alamos National Laboratory database by 2013 (http://www.hiv.lanl.gov). Although the database only has subtype distribution data from publications in the literature and is not based on the world population, the varying subtype sequence information in the database is sufficient for designing the HIV-1 oligomer set. To increase the subtype detection efficiency, the prevalence of subtypes in the world based on the Los Alamos National Laboratory database by 2013 was analyzed and the oligomer set was designed in several steps.

First, the conserved region in the pol gene was selected and primers and a probe were designed. Second, the designed primers and probe were analyzed based on various subtypes including subtypes $\mathrm{M}, \mathrm{N}$, and $\mathrm{O}$, and several sequences of 5'-primer and 5'-probe were considered especially important. Finally, the primers and probe sequence were modified to detect most of all HIV-1 subtypes in the world. The cross-reactivity of the HIV-1 oligomer set with other virus and bacteria genomes was analyzed using BLAST (http:// blast.ncbi.nlm.nih.gov/Blast.cgi). The HIV-1 probe was labeled with FAM fluorescent dye at the 5' end and BHQ1 quencher at the 3 ' end.

The internal positive control oligomer set was designed to have no cross-reactivity with the HIV-1 genome, especially the pol gene region. The TMV genome sequence was searched for in the GenBank database (http://www.ncbi.nlm.nih.gov/). The cross-reactivity of the TMV oligomer set with other virus and bacteria genomes was analyzed using BLAST (http://blast.ncbi. nlm.nih.gov/Blast.cgi). The TMV probe was labeled with TAMRA fluorescent dye at the $5^{\prime}$ end and BHQ1 quencher at the $3^{\prime}$ end.

\section{RNA extraction}

Viral RNA was extracted from $0.4 \mathrm{ml}$ of EDTA plasma with a ExiPrep ${ }^{\mathrm{TM}}$ Dx Viral RNA kit (Bioneer, Daejeon, Korea), and an automated nucleic acid extraction instrument, ExiPrep $^{\mathrm{TM}} 16$ Dx (Bioneer, Daejeon, Korea). An internal positive control consisting of RNA sequences unrelated to the HIV-1 target sequence was pre-loaded in each sample loading tube from the beginning of the RNA extraction from specimens to determine whether the nucleic acids were properly extracted and amplified in each reaction and whether PCR was not inhibited by the sample. The extraction procedure followed the manufacturer's instructions.

\section{HIV-1 quantitative RT-qPCR}

The HIV-1 RNA was amplified using the AccuPower ${ }^{\circledR}$ RocketScript $^{\mathrm{TM}}$ RT-qPCR PreMix (Bioneer, Daejeon, Korea). To increase the convenience and reproducibility of the test, oligomer sets that included HIV-1 and TMV were dried in the AccuPower $^{\circledR}$ RocketScript $^{\mathrm{TM}}$ RT-qPCR PreMix (Bioneer, Daejeon, Korea). For RT-qPCR, $50 \mu$ of the extracted sample were transferred into the AccuPower ${ }^{\circledR}$ RocketScript $^{\mathrm{TM}}$ RT-qPCR PreMix (Bioneer, Daejeon, Korea) and loaded on the Exicycler ${ }^{\mathrm{TM}} 96$ Real-Time Quantitative Thermal Block (Bioneer, Daejeon, Korea). The thermal cycling was conducted as follows: $55^{\circ} \mathrm{C}$ for $15 \mathrm{~min} ; 95^{\circ} \mathrm{C}$ for $5 \mathrm{~min} ; 45$ cycles of $95^{\circ} \mathrm{C}$ for $5 \mathrm{sec}, 55^{\circ} \mathrm{C}$ for $5 \mathrm{sec}$ and a fluorescence scan; and $25^{\circ} \mathrm{C}$ for $1 \mathrm{~min}$. The concentration of HIV-1 RNA in a sample was determined on the basis of the $\mathrm{Ct}$ value, and the corresponding concentration (IU/ml) of RNA was determined from the standard curves.

\section{Performance evaluation}

Limit of detection: The limit of detection (LoD) of the HIV-1 quantitative RT-qPCR assay was determined by testing the WHO $3^{\text {rd }}$ HIV-1 International Standard panel (NIBSC code: 10/152, UK) containing 5.27 $\log _{10} \mathrm{IU} / \mathrm{ml}$ of HIV-1, subtype B. The panel was diluted in HIV-1 negative human EDTA plasma (Seracare, Milford, USA), and a concentration of $200 \mathrm{IU} / \mathrm{ml}$ was subjected to two-fold serial 
dilution $(200,100,50,25,12.5,6.25$, and $3.13 \mathrm{IU} / \mathrm{ml})$. The LoD was determined with eight replicates each three different lots. Twenty-four replicates at each concentration were extracted using an ExiPrep ${ }^{\mathrm{TM}}$ Dx Viral RNA kit (Bioneer, Daejeon, Korea). The RT-qPCR was performed with HIV-1 quantitative RT-qPCR assay. The proportions of positive results obtained from each concentration were subjected to a $95 \%$ hit rate by probit analysis. The LoD test was performed according to CLSI guideline EP17-A.

\section{Subtype LoD}

The subtype LoD of group M of the HIV-1 quantitative RT-qPCR assay was determined by testing the HIV RNA Genotype Performance Panel PRD202 (Seracare, Milford, USA), including subtypes A, B (the LoD result of the subtype B substitute for the above LoD test), C, D, CRF01_AE, F, CRF02_AG, G, and H. The HIV RNA Genotype Performance Panel PRD202 (Seracare, Milford, USA) was diluted in HIV-1 negative human EDTA plasma Seracare, Milford, USA), and a concentration of 200 copies/ml was subjected to two-fold serial dilution $(200,100,50,25,12.5,6.25$, and 3.13 copies $/ \mathrm{ml})$. Eight replicates at each concentration were extracted using an ExiPrep ${ }^{\mathrm{TM}}$ Dx Viral RNA kit (Bioneer, Daejeon, Korea). The RT-qPCR was performed with HIV-1 quantitative RT-qPCR assay. The proportion of positive results obtained from each concentration was subjected to a $95 \%$ hit rate by probit analysis. The subtype LoD test was performed according to CLSI guideline EP17-A.

The detection limit of group $\mathrm{N}$ and $\mathrm{O}$ of the HIV-1 quantitative RT-qPCR assay was determined by testing the WHO Reference Reagent $2^{\text {nd }}$ WHO International Reference Panel Preparation for HIV-1 Subtypes for NAT (Main) (NIBSC code: $12 / 224$, UK), including groups $\mathrm{N}$ and $\mathrm{O}$. The WHO Reference Reagent $2^{\text {nd }}$ WHO International Reference Panel Preparation for HIV-1 Subtypes for NAT (Main) (NIBSC code: $12 / 224$, UK) was diluted in HIV-1 negative human EDTA plasma (Seracare, Milford, USA), and concentrations of $500,400,300,200,100$, and $50 \mathrm{IU} / \mathrm{ml}$ were serially diluted. Four replicates at each concentration were extracted using an ExiPrep ${ }^{\mathrm{TM}}$ Dx Viral RNA kit (Bioneer, Daejeon, Korea). The RT-qPCR was performed with HIV-1 quantitative RT-qPCR assay. The detection limit was represented by the concentration of $100 \%$ detection.

\section{Dynamic range}

The linearity of dynamic range of the HIV-1 quantitative RT-qPCR assay was determined by testing the HIV-1 positive control particle. The HIV-1 positive particle was diluted in HIV-1 negative human EDTA plasma (Seracare, Milford, USA), and a concentration of $3.2 \times 10^{8} \mathrm{IU} / \mathrm{ml}$ was serially diluted in ten-fold steps to $3.2 \times 10^{1} \mathrm{IU} / \mathrm{ml}$. Eight replicates at each concentration were extracted using an ExiPrep ${ }^{\mathrm{TM}}$ Dx Viral RNA kit (Bioneer, Daejeon, Korea). The RT-qPCR was performed with HIV-1 quantitative RT-qPCR assay. The standard curve was generated by the threshold cycle $(\mathrm{Ct})$ value of each concentration (X-axis) and the concentration of $\log _{10} \mathrm{IU} / \mathrm{ml}$ (Y-axis). A concentration range where $\mathrm{R}^{2}$ was greater than 0.99 was selected as the dynamic range.

\section{Precision}

The precision of the HIV-1 quantitative RT-qPCR assay was determined through the analysis of three different concentrations of HIV-1 positive particle. The HIV-1 positive particle was spiked in HIV-1 negative human EDTA plasma (Seracare, Milford, USA) with the concentrations of 3.5 $\log _{10} \mathrm{IU} / \mathrm{ml}, 5.5 \log _{10} \mathrm{IU} / \mathrm{ml}$, and $7.5 \log _{10} \mathrm{IU} / \mathrm{ml}$. The precision test was assessed with two replicates a run and two runs every day for 15 days. The precision samples were extracted using an ExiPrep ${ }^{\mathrm{TM}}$ Dx Viral RNA kit (Bioneer, Daejeon, Korea). The RT-qPCR was performed with HIV-1 quantitative RT-qPCR assay. The results of the precision test showed within-run, between-run, between-day, and total precision. The precision test was analyzed according to CLSI guideline EP05-A2.

\section{Cross-reactivity}

A total of 11 species of bacteria and viruses including HIV-1 were tested for potential cross-reactivity with the use of the HIV-1 quantitative RT-qPCR assay. The bacterial genomic DNA was extracted using an ExiPrep ${ }^{\mathrm{TM}}$ Dx Bacteria Genomic DNA kit (Bioneer, Daejeon, Korea) and viral nucleic acid was extracted using an ExiPrep ${ }^{\mathrm{TM}}$ Dx Viral DNA/RNA kit (Bioneer, Daejeon, Korea). The RT-qPCR was performed with HIV-1 quantitative RT-qPCR assay. The 
Table 1. Information of China National Reference Panel of HIV-1 RNA

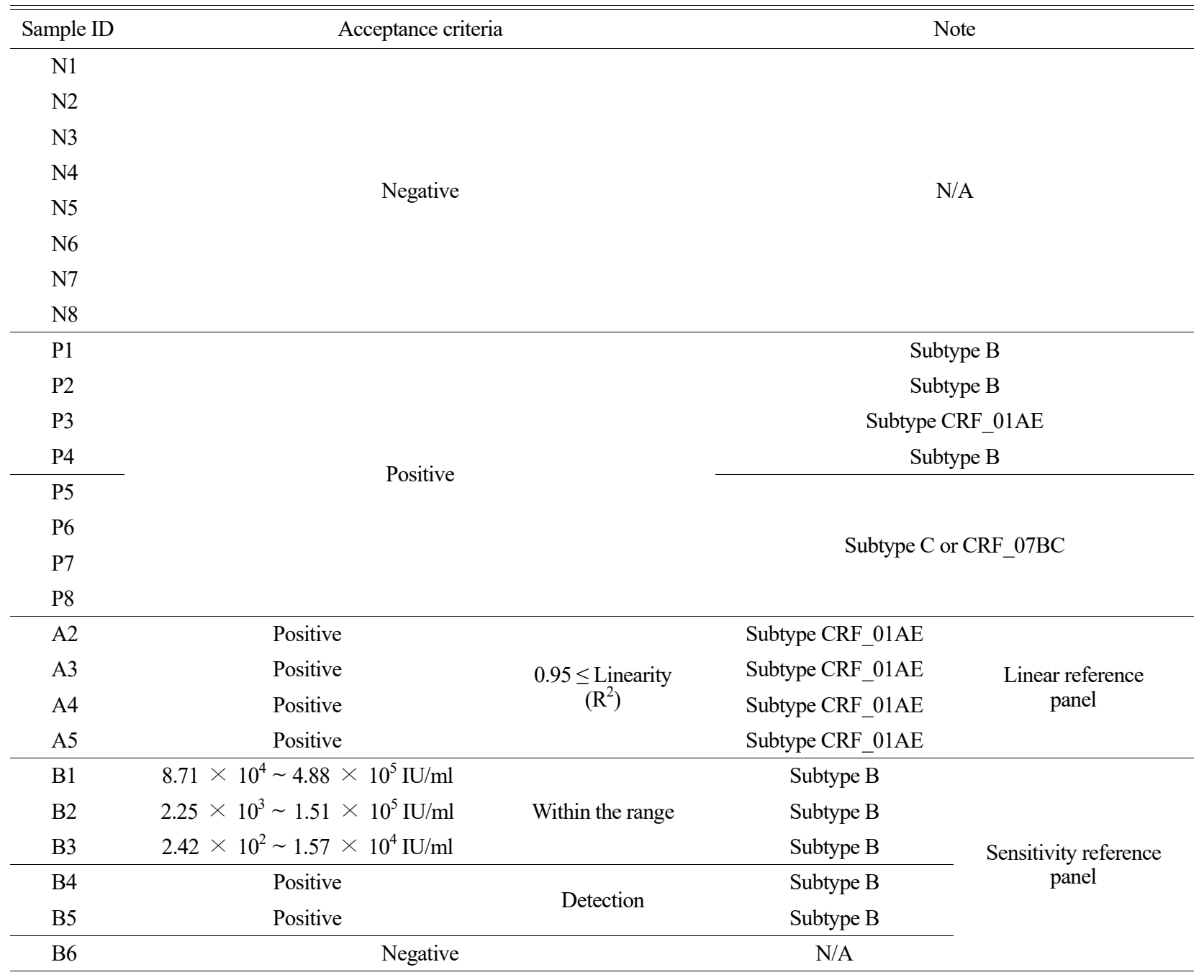

cross-reactivity test was performed with the purified nucleic acid with a concentration of $5 \log _{10}$ copy/test.

\section{China National Reference Panel of HIV-1 RNA test}

The pre-clinical evaluation of the HIV-1 quantitative RTqPCR assay was performed using the China National Reference Panel of HIV-1 RNA. The China National Reference Panel of HIV-1 RNA has four different panels, including the positive panel (P1 to P8), negative panel (N1 to N9), linearity panel (A2 to A5), and sensitivity panel (B1 to B6). All the panels have acceptance criteria and HIV-1 subtype information. Detailed information on the China National Reference Panel of HIV-1 RNA is given in Table 1.
Table 2. Clinical sample information of China evaluation

\begin{tabular}{lccc}
\hline \hline \multirow{2}{*}{ Site } & \multicolumn{3}{c}{ Sample information } \\
\cline { 2 - 3 } & & $\begin{array}{l}\text { Positive } \\
(\mathrm{N}=153)\end{array}$ & $\begin{array}{c}\text { Negative } \\
(\mathrm{N}=10)\end{array}$ \\
\hline Storage type & Fresh & Frozen & Frozen \\
\hline $\begin{array}{l}\text { Hunan CDC } \\
(\mathrm{N}=163)\end{array}$ & 64 & 77 & \multirow{2}{*}{10} \\
\cline { 3 - 3 } & & $\begin{array}{l}\text { Drug treated patient } \\
\text { samples: 12 }\end{array}$ & \\
\hline
\end{tabular}

\section{Clinical evaluation}

The clinical evaluation of the HIV-1 quantitative RTqPCR assay was performed at the Hunan Provincial Center 
for Disease Prevention and Control (CDC) in China from June to July 2014. A total of 163 EDTA-plasma clinical samples were collected from 2011 to 2014 (Table 2). The Hunan CDC samples were composed of fresh samples, frozen samples and antiretroviral drug-treated patient samples. The fresh samples were not frozen and were stored at 4 $8^{\circ} \mathrm{C}$. The frozen samples were stored at under $-20^{\circ} \mathrm{C}$. The antiretroviral drug-treated patient samples were collected from patients who had received antiretroviral drug cocktail therapy. In the Hunan CDC, the clinical evaluation was performed with HIV-1 quantitative RT-qPCR assay and a Human Immunodeficiency Virus Type 1 (HIV-1) PCR Kit (DaAn gene, Guangzhou, China). The DaAn gene kit was approved by China Food and Drug Administration (CFDA) in 2012 and is currently sold in the China.

\section{Statistical analysis}

The correlation coefficient $\left(\mathrm{R}^{2}\right)$ was used to assess the strength of the linear association between the $\log _{10} \mathrm{IU} / \mathrm{ml}$ levels in the quantified samples measured by the two assays in Hunan CDC. The Bland-Altman plot was used to assess the level of agreement between the paired measurements. The correlation coefficient, the Bland-Altman plot, the mean differences, and the standard deviation (SD) were generated using SPSS 18.0 software (SPSS Inc., Chicago, USA) (Park et al., 2015).

\section{RESULTS}

\section{Oligomer design}

According to the Los Alamos National Laboratory database by 2013 , the most prevalent HIV-1 subtypes are B, C, A, and CRF01_AE. The HIV-1 oligomer set was designed to detect major subtypes, such as subtypes B, C, A, and CRF01-AE, as well as minor subtypes, as shown in Table 3. The candidate sequences of primers and probe were analyzed based on various subtypes, including subtypes $\mathrm{M}, \mathrm{N}$, and $\mathrm{O}$. The mismatch ratio of each sequence position was calculated

Table 3. Oilgo sets of HIV-1 quantitative RT-qPCR assay

\begin{tabular}{lllc}
\hline \hline \multirow{2}{*}{ Oligomer name } & \multicolumn{1}{c}{ Sequence (5' to 3') } & \multicolumn{2}{c}{ Modification } \\
\cline { 2 - 3 } HIV forward & & $5^{\prime}$ & $3^{\prime}$ \\
HIV reverse & CCH $^{1} \mathrm{M}^{2}$ TTTGGAAAGGACCAGC & N/A & N/A \\
HIV probe & $\mathrm{CR}^{3} \mathrm{Y}^{4}$ CTGCCATCTGTTTTCCATA & N/A & BHQ1 \\
TMV forward & CTYTGGAAAGGTGAAGGGGCAGT & FAM & N/A \\
TMV reverse & AGATTTCAGTTCAAGGTCGTTC & N/A & N/A \\
TMV probe & GAAACCCGCTGACATCTT & TAMRA & BHQ1 \\
\hline
\end{tabular}

*N/A: not applicable

Mixed base code information

${ }^{1} \mathrm{H}=\mathrm{A}+\mathrm{T}+\mathrm{C},{ }^{2} \mathrm{M}=\mathrm{A}+\mathrm{C},{ }^{3} \mathrm{R}=\mathrm{A}+\mathrm{G},{ }^{4} \mathrm{Y}=\mathrm{C}+\mathrm{T}$

Table 4. Detection rate of several concentrations with WHO $3^{\text {rd }}$ HIV-1 International Standard panel using HIV-1 quantitative RT-qPCR assay

\begin{tabular}{lccccccc}
\hline \hline \multirow{2}{*}{ Lot } & \multicolumn{7}{c}{ WHO $^{\text {rd }}$ HIV-1 International Standard panel conc. (IU/ml) } \\
\cline { 2 - 8 } & 200 & 100 & 50 & 25 & 12.5 & 6.25 & 3.13 \\
$(\mathrm{~N}=24)$ & $(\mathrm{N}=24)$ & $(\mathrm{N}=24)$ & $(\mathrm{N}=24)$ & $(\mathrm{N}=24)$ & $(\mathrm{N}=24)$ & $(\mathrm{N}=24)$ \\
\hline $1^{\text {st }}(\mathrm{N}=8)$ & 8 & 8 & 8 & 8 & 5 & 4 & 1 \\
$2^{\text {nd }}(\mathrm{N}=8)$ & 8 & 8 & 8 & 8 & 3 & 2 & 1 \\
$3^{\text {rd }}(\mathrm{N}=8)$ & 8 & 8 & 8 & 7 & 3 & 2 & 1 \\
Total $(\mathrm{N}=24)$ & 24 & 24 & 24 & 23 & 11 & 8 & 3 \\
\hline Detection ratio (\%) & 100.00 & 100.00 & 100.00 & 95.83 & 45.83 & 33.33 & 12.50
\end{tabular}


in the Los Alamos National Laboratory database by 2013 (http://www.hiv.lanl.gov). In the forward primer, the mismatch of each sequence position was shown at the $3^{\text {rd }}$ and $4^{\text {th }}$ positions. The matching points $(\%)$ of the candidate forward primer sequence at the $3^{\text {rd }}$ and $4^{\text {th }}$ positions were $68.51 \%$ and $59.49 \%$, respectively. In the reverse primer, there was no significant mismatch position. In the probe, the mismatch of the sequence position was shown at the $3^{\text {rd }}$ position. The matching point (\%) of the candidate probe sequence at the $3^{\text {rd }}$ position was $85.93 \%$. To increase HIV-1 subtype coverage, the HIV-1 oligomer set had several multiplex sequences at the mismatch position.

\section{Performance evaluation}

Limit of detection (LoD): The detection rates of several concentrations of the WHO $3{ }^{\text {rd }} \mathrm{HIV}-1$ International Standard panel by the HIV-1 quantitative RT-qPCR assay are shown in Table 4. The LoD was determined with three different lots. The assay with all of three lots detected up to $50 \mathrm{IU} / \mathrm{ml}$. Only one sample was not detected at $25 \mathrm{IU} / \mathrm{ml}$ using the $3^{\text {rd }}$

Table 5. Subtypes LoD of HIV-1 quantitative RT-qPCR assay

\begin{tabular}{lcc}
\hline \multirow{2}{*}{ Subtype } & \multicolumn{2}{c}{ Limit of Detection $(\mathrm{LoD})$} \\
\cline { 2 - 3 } & Copy/ml & $\mathrm{IU} / \mathrm{ml}$ \\
\hline A & 33.1 & 26.1 \\
C & 21.4 & 16.9 \\
D & 21.4 & 16.9 \\
CRF01_AE & 41.7 & 32.9 \\
F & 47.9 & 37.8 \\
CRF02_AG & 28.2 & 22.3 \\
G & 47.8 & 37.8 \\
H & 32.3 & 25.5 \\
\hline
\end{tabular}

lot. The proportions of positive results obtained from each concentration were subjected to a $95 \%$ hit rate by probit analysis. The LoD of HIV-1 quantitative RT-qPCR assay was $33.9 \mathrm{IU} / \mathrm{ml}$ (= $43.1 \mathrm{copy} / \mathrm{ml})$.

\section{Subtype LoD}

LoD of the subtypes by HIV-1 quantitative RT-qPCR assay are shown in Table 5. The detection rates of groups $\mathrm{N}$ and $\mathrm{O}$ are shown in Table 6 . The groups $\mathrm{N}$ and $\mathrm{O}$ samples were detected up to $100 \mathrm{IU} / \mathrm{ml}$ and $200 \mathrm{IU} / \mathrm{ml}$, respectively.

\section{Dynamic range}

The dynamic range of HIV-1 quantitative RT-qPCR assay was established using HIV-1 positive particles that were diluted in HIV-1 negative human EDTA plasma (Seracare, Milford, USA) and a concentration of $3.2 \times 10^{8} \mathrm{IU} / \mathrm{ml}$ was serially diluted in ten-fold steps to $3.2 \times 10^{1} \mathrm{IU} / \mathrm{ml}$. The observed $\mathrm{Ct}$ values were plotted against the concentrations of the samples. The linearity ( $\mathrm{R}^{2}$ value) of HIV-1 quantitative RT-qPCR assay with $3.2 \times 10^{1} \mathrm{IU} / \mathrm{ml}$ to $3.2 \times$ $10^{8} \mathrm{IU} / \mathrm{ml}$ was 0.998 . Thus, the dynamic range of HIV-1 quantitative RT-qPCR assay was $3.2 \times 10^{1} \mathrm{IU} / \mathrm{ml}$ to $3.2 \times$ $10^{8} \mathrm{IU} / \mathrm{ml}$.

\section{Precision}

The precision including within-run, between-run, betweenday, and total precision was analyzed according to CLSI guideline EP05-A2. The within-run was assessed with two replicates of three different HIV-1 positive control concentrations of $3.5 \log _{10} \mathrm{IU} / \mathrm{ml}, 5.5 \log _{10} \mathrm{IU} / \mathrm{ml}$, and 7.5 $\log _{10}$ $\mathrm{IU} / \mathrm{ml}$. The estimates of repeatability (within-run) standard deviation $\left(\mathrm{S}_{\mathrm{r}}\right)$ at each concentration were $0.16,0.15$, and 0.15 , respectively (Table 7 ). The between-run was assessed

Table 6. Detection rate of group $\mathrm{N}$ and $\mathrm{O}$ using HIV-1 quantitative RT-qPCR assay

\begin{tabular}{ccccccc}
\hline \hline & \multicolumn{5}{c}{ WHO Reference Reagent $2^{\text {nd }}$ WHO International Reference Panel Preparation for } \\
HIV-1 Subtypes for NAT (Main) (IU/ml) \\
\cline { 2 - 8 } Group & 500 & 400 & 300 & 200 & 100 & 50 \\
& $(\mathrm{~N}=4)$ & $(\mathrm{N}=4)$ & $(\mathrm{N}=4)$ & 4 & $(\mathrm{~N}=4)$ & 4 \\
$(\mathrm{~N}=4)$ & 3 \\
$\mathrm{~N}$ & 4 & 4 & 4 & 4 & 3 & 1 \\
\hline
\end{tabular}


Table 7. Within-run, between-run, between-day and total precision of HIV-1 quantitative RT-qPCR assay

\begin{tabular}{cccccc}
\hline \hline $\begin{array}{c}\text { Conc. } \\
\left(\log _{10} \mathrm{IU} / \mathrm{ml}\right)\end{array}$ & $\begin{array}{c}\text { Within-Run } \\
\left(\mathrm{S}_{\mathrm{r}}\right)\end{array}$ & $\begin{array}{c}\text { Between-Run } \\
\left(\mathrm{S}_{\mathrm{rr}}\right)\end{array}$ & $\begin{array}{c}\text { Between-Day } \\
\left(\mathrm{S}_{\mathrm{dd}}\right)\end{array}$ & $\begin{array}{c}\text { Total precision } \\
\left(\mathrm{S}_{\mathrm{T}}\right)\end{array}$ & $\begin{array}{c}\text { Coefficient of variation } \\
(\mathrm{CV}, \%)\end{array}$ \\
\hline 3.5 & 0.16 & 0.04 & 0.11 & 0.2 & 5.32 \\
5.5 & 0.15 & 0.05 & 0.14 & 0.21 & 3.67 \\
7.5 & 0.15 & 0.03 & 0.08 & 0.17 & 2.18 \\
\hline
\end{tabular}

with two runs per day. The estimates of between-run standard deviation $\left(\mathrm{S}_{\mathrm{rr}}\right)$ at each concentration were $0.04,0.05$, and 0.03 , respectively. The between day was assessed with 15 days. The estimates of between-day standard deviation $\left(\mathrm{S}_{\mathrm{dd}}\right)$ at each concentration were $0.11,0.14$, and 0.08 , respectively. The total precision $\left(\mathrm{S}_{\mathrm{T}}\right)$ and coefficient of variation $(\mathrm{CV}, \%)$ were calculated using the standard deviation of all observed data. The $\mathrm{S}_{\mathrm{T}}$ and CV (\%) of HIV-1 quantitative RT-qPCR assay were 0.2 (5.32\%), 0.21 (3.67\%), and 0.17 (2.18) at concentrations of $3.5 \log _{10} \mathrm{IU} / \mathrm{ml}, 5.5 \log _{10} \mathrm{IU} /$ $\mathrm{ml}$, and $7.5 \log _{10} \mathrm{IU} / \mathrm{ml}$, respectively.

\section{Cross-reactivity}

The cross-reactivity of HIV-1 quantitative RT-qPCR assay was evaluated by adding various bacteria (Bacillus cereus, Staphylococcus aureus, and Escherichia coli) and virus (hepatitis $\mathrm{C}$ virus, cytomegalovirus, Epstein-Barr virus, BK virus, human papilloma virus type 16 , papilloma virus type 18 , and adenovirus) nucleic acid with the concentration of $5 \log _{10}$ copy/test. None of the organisms tested, except HIV-1, showed cross-reactivity with HIV-1 quantitative RTqPCR assay.

\section{China National Reference Panel of HIV-1 RNA test}

The HIV-1 quantitative RT-qPCR assay was evaluated using the China National Reference Panel of HIV-1 RNA to determine the analytical performance. The results of this evaluation using various panels that included the negative panel (N1 to N8), positive panel (P1 to P8), linearity panel (A2 to A4), and sensitivity panel (B1 to B5, B6 is a negative sample) are described in Table 8 . The positive panel (P1 to P8) was quantified (or detected), and the negative panel (N1 to N8) was not detected. For the analysis of linearity using the linearity panel (A2 to A5), the observed $\mathrm{Ct}$ values were plotted against concentration. The linearity $\left(\mathrm{R}^{2}\right.$ value) of the HIV-1 quantitative RT-qPCR assay with the linearity panel (A2 to A5) was 0.9805 . The $\mathrm{R}^{2}$ value was within the acceptance criteria $\left(0.95 \leq R^{2}\right)$. The quantitative results were obtained with the sensitivity panel (B1 to B5), and the B6 sample was not detected. All the quantitative results were within the quantitative acceptance range.

\section{Clinical evaluation}

In Hunan $\mathrm{CDC}$, the clinical evaluation was performed with HIV-1 quantitative RT-qPCR assay and a Human Immunodeficiency Virus Type 1 (HIV-1) PCR Kit (DaAn gene, Guangzhou, China) using 163 clinical samples. The samples were composed of fresh samples (positive, $\mathrm{N}=64$ ), frozen samples (positive, $\mathrm{N}=77$, negative samples (healthy people, $\mathrm{N}=10$ ), and antiretroviral drug-treated patient samples $(\mathrm{N}=12)$. All of the 64 tested fresh positive samples were quantified with both assays. The average viral loads ( $\log _{10} \mathrm{IU} / \mathrm{ml}$ ) with the 64 samples measured using the HIV-1 quantitative RT-qPCR assay and Human Immunodeficiency Virus Type 1 (HIV-1) PCR Kit (DaAn gene, Guangzhou, China) were $5.16(\mathrm{SD}=0.62)$ and $4.42(\mathrm{SD}=0.92)$, respectively. Of the 77 frozen positive samples, 76 were quantified with both assays. The average viral loads $\left(\log _{10} \mathrm{IU} / \mathrm{ml}\right)$ with the 76 samples measured using the HIV-1 quantitative RT-qPCR assay and Human Immunodeficiency Virus Type 1 (HIV-1) PCR Kit (DaAn gene, Guangzhou, China) were $4.70(\mathrm{SD}=0.72)$ and $4.60(\mathrm{SD}=0.91)$, respectively. One frozen positive sample was found to be negative by both assays. All of the 10 tested negative samples were not detected with both assays (Table 9). The sensitivity and specificity of HIV-1 quantitative RT-qPCR assay were 99\% and 100\%, respectively.

The HIV-1 quantitative RT-qPCR assay showed a signifi- 
Table 8. Results of HIV-1 quantitative RT-1PCR assay for China National Reference Panel of HIV-1 RNA test

\begin{tabular}{|c|c|c|c|c|c|}
\hline \multirow{2}{*}{ Sample ID } & \multirow{2}{*}{ Acceptance criteria } & & \multicolumn{3}{|c|}{ Observed results } \\
\hline & & & $\mathrm{Ct}$ & Conc. (IU/ml) & $\mathrm{R}^{2}$ \\
\hline N1 & \multirow{8}{*}{\multicolumn{2}{|c|}{ Negative }} & UD & - & \multirow{16}{*}{ N/A } \\
\hline N2 & & & UD & - & \\
\hline N3 & & & UD & - & \\
\hline N4 & & & UD & - & \\
\hline N5 & & & UD & - & \\
\hline N6 & & & UD & - & \\
\hline N7 & & & UD & - & \\
\hline N8 & & & UD & - & \\
\hline $\mathrm{P} 1$ & \multirow{8}{*}{ Positive } & & 28.63 & $7.90 \times 10^{4}$ & \\
\hline $\mathrm{P} 2$ & & & 29.88 & $3.40 \times 10^{4}$ & \\
\hline P3 & & & 29.7 & $3.84 \times 10^{4}$ & \\
\hline P4 & & & 27.57 & $1.61 \times 10^{5}$ & \\
\hline P5 & & & 24.32 & $1.44 \times 10^{6}$ & \\
\hline P6 & & & 24.39 & $1.37 \times 10^{6}$ & \\
\hline P7 & & & 29.51 & $4.37 \times 10^{4}$ & \\
\hline P8 & & & 32.4 & $6.24 \times 10^{3}$ & \\
\hline A2 & Positive & & 28.47 & $8.79 \times 10^{4}$ & \multirow{4}{*}{0.9805} \\
\hline $\mathrm{A} 3$ & Positive & $0.95 \leq$ & 31.25 & $1.35 \times 10^{4}$ & \\
\hline A4 & Positive & Linearity $\left(\mathrm{R}^{2}\right)$ & 34.52 & $1.50 \times 10^{3}$ & \\
\hline A5 & Positive & & 39.53 & $5.14 \times 10^{1}$ & \\
\hline B1 & $8.71 \times 10^{4} \sim 4.88 \times 10^{5} \mathrm{IU} / \mathrm{ml}$ & \multirow{3}{*}{$\begin{array}{l}\text { Within } \\
\text { the range }\end{array}$} & 26.85 & $2.62 \times 10^{5}$ & \multirow{6}{*}{$\mathrm{N} / \mathrm{A}$} \\
\hline $\mathrm{B} 2$ & $2.25 \times 10^{3} \sim 1.51 \times 10^{5} \mathrm{IU} / \mathrm{ml}$ & & 30.21 & $2.73 \times 10^{4}$ & \\
\hline B3 & $2.42 \times 10^{2} \sim 1.57 \times 10^{4} \mathrm{IU} / \mathrm{ml}$ & & 33.47 & $3.04 \times 10^{3}$ & \\
\hline B4 & Positive & \multirow{2}{*}{ Detection } & 36.33 & $4.43 \times 10^{2}$ & \\
\hline B5 & Positive & & 38.83 & $8.24 \times 10^{1}$ & \\
\hline B6 & Negative & & UD & - & \\
\hline
\end{tabular}

Table 9. Comparison of HIV-1 quantitative RT-qPCR assay versus Immunodeficiency Virus Type 1 (HIV-1) PCR Kit for the 151 clinical samples in Hunan CDC

\begin{tabular}{cccc}
\hline \hline \multirow{2}{*}{$\begin{array}{c}\text { Results with HIV-1 quantitative } \\
\text { RT-qPCR assay }\end{array}$} & \multicolumn{3}{c}{ No. of samples with the following result with } \\
& Human Immunodeficiency Virus Type 1 (HIV-1) PCR Kit \\
\cline { 2 - 4 } & 140 & Undetected & Total \\
\hline Quantified & 0 & 0 & 110 \\
Undetected & 140 & 11 & 11 \\
\hline Total & &
\end{tabular}

cant correlation coefficient $\left(\mathrm{R}^{2}\right)$ with the Human Immunodeficiency Virus Type 1 (HIV-1) PCR Kit (DaAn gene, Guangzhou, China) $\left(\mathrm{R}^{2}=0.84, P<0.001\right)$ for fresh samples that were quantitative in both assays (Fig. 1A), with high agreement $(98.4 \%, 63 / 64)$ according to the Bland-Altman plot (Fig. 1B). The fitted regression equation was $\mathrm{Y}=$ 
A

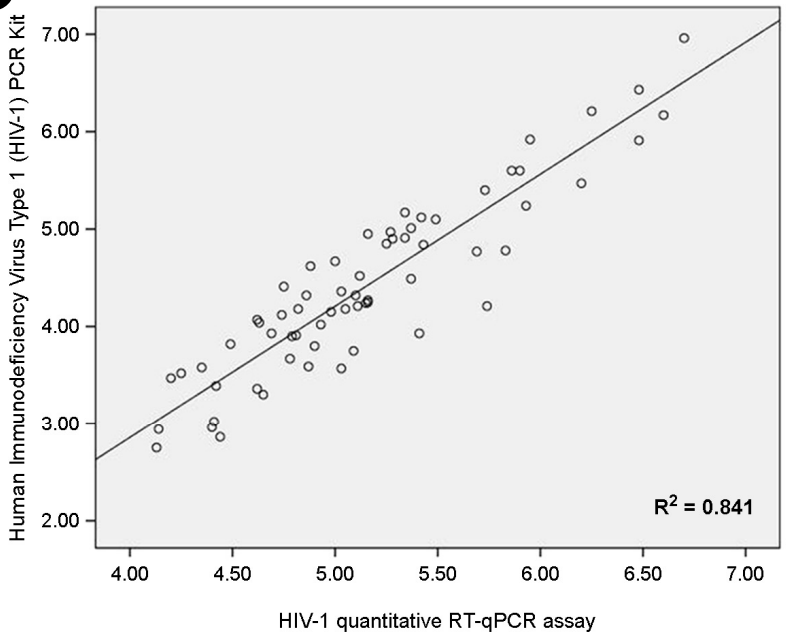

B

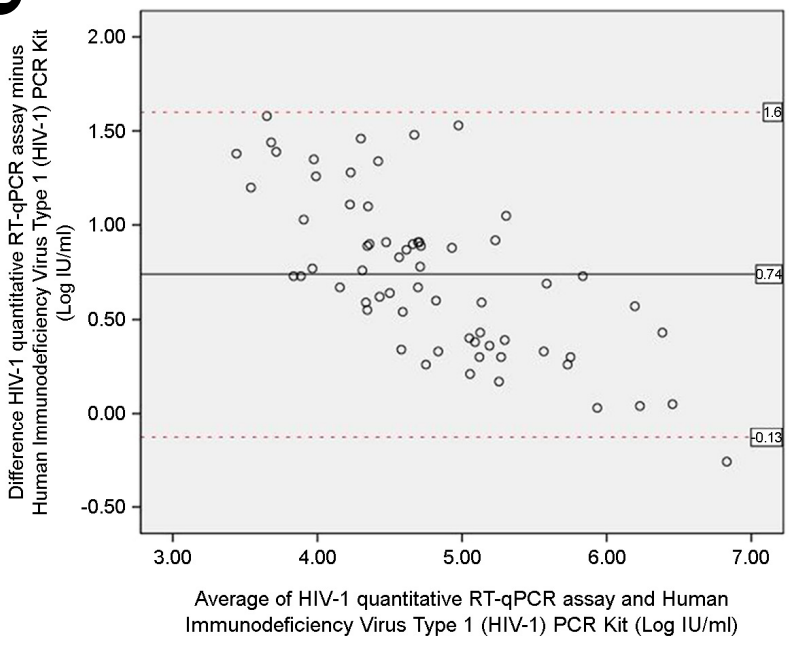

Fig. 1. Correlation of HIV-1 RNA levels and Bland-Altman plot for comparison between two assays using fresh samples. Correlation of HIV-1 RNA levels from quantified fresh samples obtained using the HIV-1 quantitative RT-qPCR assay with those obtained using the Human Immunodeficiency Virus Type 1 (HIV-1) PCR Kit (A), agreement between the the HIV-1 quantitative RT-qPCR assay and Human Immunodeficiency Virus Type 1 (HIV-1) PCR Kit calculated using the Bland-Altman model. Solid horizontal lines indicate the mean values, and red-dashed horizontal lines indicate the $\pm 2 \mathrm{SD}$ values $(\mathrm{B})$.

A

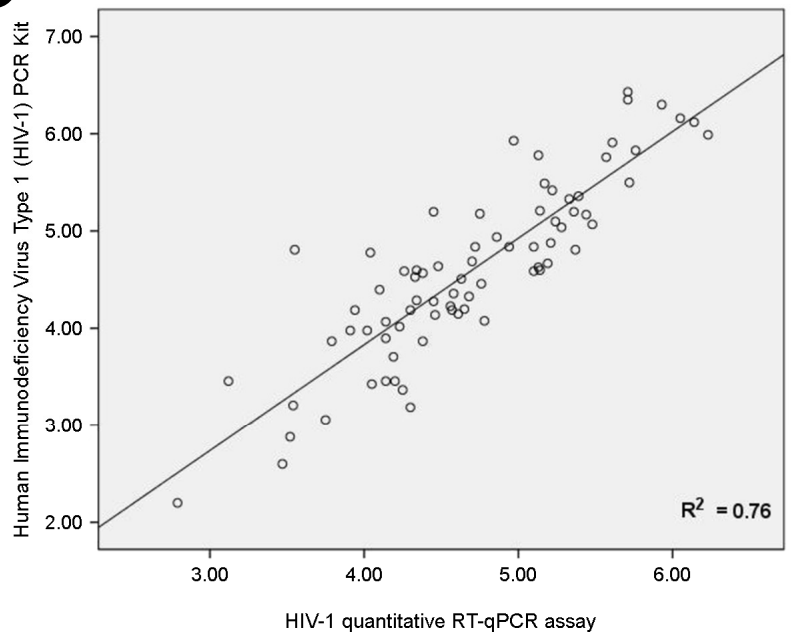

B

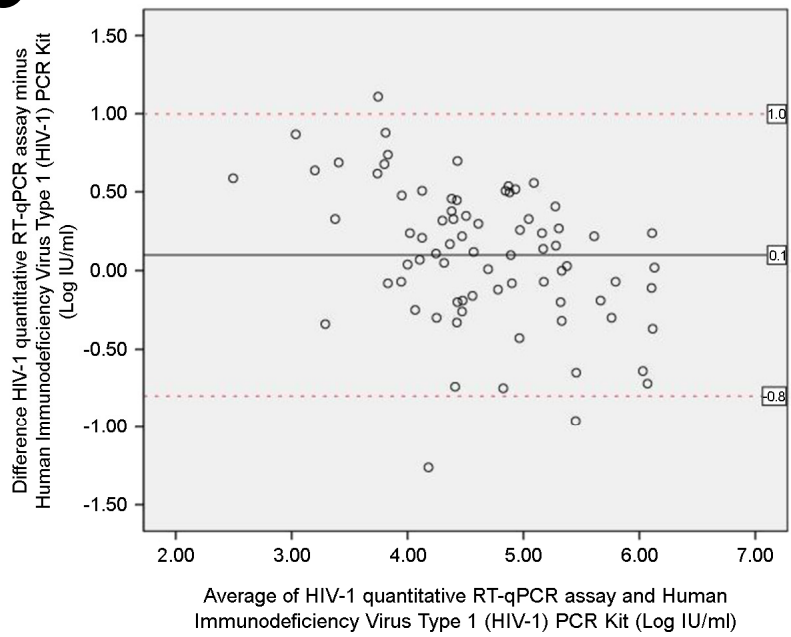

Fig. 2. Correlation of HIV-1 RNA levels and Bland-Altman plot for comparison between two assays using frozen samples. Correlation of HIV-1 RNA levels from quantified frozen samples obtained using the HIV-1 quantitative RT-qPCR assay with those obtained using the Human Immunodeficiency Virus Type 1 (HIV-1) PCR Kit (A), agreement between the the HIV-1 quantitative RT-qPCR assay and Human Immunodeficiency Virus Type 1 (HIV-1) PCR Kit calculated using the Bland-Altman model. Solid horizontal lines indicate the mean values, and red-dashed horizontal lines indicate the $\pm 2 \mathrm{SD}$ values $(\mathrm{B})$.

1.3549X-2.5651. The mean difference between the quantitative values measured by HIV-1 quantitative RT-qPCR assay and the Human Immunodeficiency Virus Type 1 (HIV1) PCR Kit (DaAn gene, Guangzhou, China) was $0.74 \log _{10}$
$\mathrm{IU} / \mathrm{ml}(\mathrm{SD}=0.43)$. The HIV-1 quantitative RT-qPCR assay showed a significant correlation coefficient $\left(\mathrm{R}^{2}\right)$ with the Human Immunodeficiency Virus Type 1 (HIV-1) PCR Kit (DaAn gene, Guangzhou,China) $\left(\mathrm{R}^{2}=0.76, P<0.001\right)$ for 
Table 10. Quantitative result of two assays for antiretroviral drug treated patient samples

\begin{tabular}{cccc}
\hline \hline \multirow{2}{*}{ Sample No. } & $\begin{array}{c}\text { Antiviral drug } \\
\text { information }\end{array}$ & HIV-1 quantitative RT-qPCR assay & $\begin{array}{c}\text { Human Immunodeficiency Virus Type 1 } \\
\text { (HIV-1) PCR Kit }\end{array}$ \\
\cline { 3 - 4 } & $\mathrm{NVP}^{1}+3 \mathrm{TC}^{2}+\mathrm{AZT}^{3}$ & Conc. $\left(\log _{10} \mathrm{IU} / \mathrm{ml}\right)$ & 1.11 \\
\hline 2 & $\mathrm{NVP}+3 \mathrm{TC}+\mathrm{AZT}$ & 1.80 & 0.85 \\
3 & $\mathrm{NVP}+3 \mathrm{TC}+\mathrm{d} 4 \mathrm{~T}^{4}$ & 2.62 & 2.14 \\
4 & $\mathrm{NVP}+3 \mathrm{TC}+\mathrm{AZT}$ & 2.29 & 0.48 \\
5 & $\mathrm{EFV}+3 \mathrm{TC}+\mathrm{TDF}^{6}$ & 1.18 & 1.66 \\
6 & $\mathrm{NVP}+3 \mathrm{TC}+\mathrm{AZT}$ & 2.52 & 1.69 \\
7 & $\mathrm{EFV}+3 \mathrm{TC}+\mathrm{TDF}$ & 2.77 & 2.25 \\
8 & $\mathrm{NVP}+3 \mathrm{TC}+\mathrm{AZT}$ & 2.39 & 1.76 \\
9 & $\mathrm{NVP}+3 \mathrm{TC}+\mathrm{d} 4 \mathrm{~T}$ & Undetermined & Undetermined \\
10 & $\mathrm{EFV}+3 \mathrm{TC}+\mathrm{AZT}$ & 1.83 & Undetermined \\
11 & $\mathrm{NVP}+3 \mathrm{TC}+\mathrm{AZT}$ & Undetermined & Undetermined \\
12 & $3 \mathrm{TC}+\mathrm{TDF}+\mathrm{Aluvia}$ & Undetermined & Undetermined \\
\hline
\end{tabular}

Antiretroviral drug name

${ }^{1}$ NVP; Nevirapine, ${ }^{2}$ 3TC; Lamivudine or Epivir, ${ }^{3}$ AZT; Zidoudine or Retrovir, ${ }^{4} \mathrm{~d} 4 \mathrm{~T}$; Stavudine or Zerit, ${ }^{5} \mathrm{EFV}$; Efavirenz, ${ }^{6} \mathrm{TDF}$; Viread,

${ }^{7}$ Aluvia; Lopinavir and Ritonavir

frozen samples that were quantitative in both assays (Fig. $2 \mathrm{~A})$, with high agreement $(96.1 \%, 73 / 76)$ according to the Bland-Altman plot (Fig. 2B). The fitted regression equation used was $\mathrm{Y}=1.0951 \mathrm{X}-0.5464$. The mean difference between the quantitative values measured by HIV-1 quantitative RTqPCR assay and the Human Immunodeficiency Virus Type 1 (HIV-1) PCR Kit (DaAn gene, Guangzhou, China) was $0.1 \log _{10} \mathrm{IU} / \mathrm{ml}(\mathrm{SD}=0.45)$.

A total of 12 antiretroviral drug-treated patient samples were tested with both assays. Seven samples were quantified with both assays. The average viral loads of the seven samples measured by the HIV-1 quantitative RT-qPCR assay and the Human Immunodeficiency Virus Type 1 (HIV-1) PCR Kit (DaAn gene, Guangzhou, China) were $256 \mathrm{IU} / \mathrm{ml}$ and $62 \mathrm{IU} / \mathrm{ml}$, respectively. The two samples were quantified with the HIV-1 quantitative RT-qPCR assay, while HIV-1 was not detected with the Human Immunodeficiency Virus Type 1 (HIV-1) PCR Kit (DaAn gene, Guangzhou, China) (quantitative results 68 and $79 \mathrm{IU} / \mathrm{ml}$ for the HIV-1 quantitative RT-qPCR assay). One sample was quantified with the Human Immunodeficiency Virus Type 1 (HIV-1) PCR Kit (DaAn gene, Guangzhou, China), while HIV-1 was not detected with the HIV-1 quantitative RT-qPCR assay (quan- titative result $57 \mathrm{IU} / \mathrm{ml}$ for the Human Immunodeficiency Virus Type 1 [HIV-1] PCR Kit) (Table 10).

\section{DISCUSSION}

To improve detection of the pathogens for clinical diagnosis, development of molecular diagnostic tools is important. In particular, RT-qPCR assay provide quantitative results with high specificity, sensitivity and reproducibility and reduced risk of carry-over contamination (Jung et al., 2016; Oh et al., 2016). Viral load is the most important indicator of initial and sustained response to ART at the initiation of therapy and on a regular basis thereafter (AIDSinfor, 2014). Thus, to improve HIV-1-infected patients' clinical management, it is important that HIV-1 viral load assay has an acceptance detection limit and detects various subtypes (Swanson et al., 2005).

The LoD for the HIV-1 quantitative RT-qPCR assay using the WHO $3^{\text {rd }}$ HIV-1 International Standard panel was 33.9 $\mathrm{IU} / \mathrm{ml}$, which was lower than or similar to that of other commercial real-time PCR systems (Abbott RealTime HIV1, $68 \mathrm{IU} / \mathrm{ml}$ for sample vol. $1 \mathrm{ml} ; 68 \mathrm{IU} / \mathrm{ml}$ for sample vol. $0.6 \mathrm{ml} ; 75 \mathrm{IU} / \mathrm{ml}$ for sample vol. $0.5 \mathrm{ml} ; 150 \mathrm{IU} / \mathrm{ml}$ for 
sample vol. $0.2 \mathrm{ml}$; artus HI Virus-1 QS-RGQ kit, 76.4 IU/ ml; COBAS AmpliPrep/COBAS TaqMan HIV-1 Test, Ver. 2.0, 33.4 IU/ml) (Abbott, 2009; Quagen, 2012; Roche, 2013). The LoD of the HIV-1 quantitative RT-qPCR assay was similar to that of AmpliPrep/COBAS TaqMan HIV-1 Test, Ver. 2.0 (Roche Diagnostics, Branchburg, USA) that showed the lowest LoD among the commercial kits using real-time PCR method, even though the HIV-1 quantitative RT-qPCR assay uses $0.4 \mathrm{ml}$ of plasma sample while AmpliPrep/ COBAS TaqMan HIV-1 Test, Ver. 2.0 (Roche Diagnostics, Branchburg, USA) uses $1.0 \mathrm{ml}$ of plasma sample for a test. The HIV-1 quantitative RT-qPCR assay was able to detect the HIV-1 group N and O. However, other commercial realtime PCR systems do not guarantee the ability to detect both types of HIV-1 group $\mathrm{N}$ and O. The AmpliPrep/COBAS TaqMan HIV-1 Test Ver. 2.0 (Roche Diagnostics, Branchburg, USA) and Abbott RealTime HIV-1 (Abbott, Des Plaines, USA) only guarantee detection of HIV-1 group O (Abbott, 2009; Roche, 2013). The HIV-1 quantitative RT-qPCR assay was able to detect HIV-1 RNA at a concentration lower than 45 copies/ml and meet the status of optimal viral suppression (HIV-1 RNA 20 to 75 copies/ml, depending of the assay used) (AIDSinfor, 2014) and several guideline of virological failure definition (Amendola et al., 2014). This suggests that the HIV-1 quantitative RT-qPCR assay is suitable for monitoring the therapeutic effect on HIV-1 virus.

The genetic diversity of HIV-1 has important implications for diagnostic testing, patient monitoring, and therapeutic outcome. All nucleic acid amplification of signal amplification technologies rely on HIV-1 sequence-specific primers and/or probes. Thus, mismatches at primer and probe sites have the potential to reduce the efficiency of hybridization, resulting in under-quantification or the inability to detect viral RNA. Continued evolution including ART-associated mutations, and the ever-changing global distribution of HIV-1 groups/subtypes make it prudent to monitor the impact of genetic diversity on the performance of commercially available viral load tests (Swanson et al., 2005). In this study, the oligomer set of HIV-1 was designed to detect major subtypes, such as B, C, A, and CRF01-AE, and minor subtypes. The study results showed that the oligomer set of HIV-1-targeting pol genes was a highly suitable for various
HIV-1 subtypes, thereby reducing the risk of quantification bias of subtypes.

The HIV-1 quantitative RT-qPCR assay was able to detect less than $40 \mathrm{IU} / \mathrm{ml}$ of subtypes of group $\mathrm{M}$. The value of subtype LoD for HIV-1 quantitative RT-qPCR assay was lower than or similar to that of other commercial real-time PCR systems (Abbott, 2009; Quagen, 2012; Roche, 2013). The HIV-1 quantitative RT-qPCR assay was demonstrated to be capable of detecting various HIV-1 subtypes through the clinical evaluation of Beijing CDC. Furthermore, the HIV-1 quantitative RT-qPCR assay was able to detect the groups $\mathrm{N}$ and $\mathrm{O}$, while several commercial kits were not able to detect these groups.

Managing the linearity and accuracy of a HIV-1 viral load assay is critical in the implementation of a clinical laboratory. In particular, the accuracy of quantitative results is an important factor for the therapeutic monitoring of HIV-1infected patients. The linearity of the HIV-1 quantitative RT-qPCR assay was $3.2 \times 10^{1} \mathrm{IU} / \mathrm{ml}$ to $3.2 \times 10^{8} \mathrm{IU} / \mathrm{ml}$, which was similar to that of other commercial real-time PCR systems (Abbott RealTime HIV-1, 40 to $10^{8}$ copies $/ \mathrm{ml}$ for sample vol. $1 \mathrm{ml}$; artus HI Virus-1 QS-RGQ kit, $10^{2}$ to $10^{8}$ IU/ml; COBAS AmpliPrep/COBAS TaqMan HIV-1 Test, Ver. 2.0, 20 to $10^{7}$ copies $/ \mathrm{ml}$ ) (Abbott, 2009; Quagen, 2012; Roche, 2013). The precision of the HIV-1 quantitative RTqPCR assay was determined to be below $0.3 \log _{10} \mathrm{IU} / \mathrm{ml}$ at three different concentrations.

The HIV-1 quantitative RT-qPCR assay is intended to be used in the therapeutic monitoring of HIV-1-infected patients According to the recommendations on the frequency of viral load tests, the viral load should be measured before the initiation of ART and within 2 to 4 weeks, but no later than 8 weeks after treatment initiation or modification (AIDSinfor, 2014). Thus, the assay should be able to detect the viral load accurately without the interference of antiretroviral drugs in clinical samples during the therapeutic progress in HIV-1-infected patient. Of the 12 antiretroviral drug-treated patient samples in Hunan CDC, nine samples were quantified in the HIV-1 quantitative RT-qPCR assay, while eight samples were quantified in the Human Immunodeficiency Virus Type 1 (HIV-1) PCR Kit (DaAn gene, Guangzhou, China). Cross-reactions with other bacteria and 
viruses were not observed. The results of linearity, precision, interfering substances testing, and cross-reactivity indicate that the HIV-1 quantitative RT-qPCR assay is a reliable tool for the therapeutic monitoring of HIV-1-infected patients.

The China National Reference Panel of HIV-1 RNA was used for determining the performance of the HIV-1 quantitative RT-qPCR assay before beginning the clinical evaluation. The China National Reference Panel of HIV-1 RNA is used to evaluate the performance of HIV-1 diagnostic assay required for registration of CFDA. The panel is composed of negative, positive, linearity, and sensitivity panels that are able to confirm the performance of the HIV-1 viral load assay. All the results of the China National Reference Panel of HIV-1 RNA test were within the acceptance criteria. These results showed that the HIV-1 quantitative real-time RT-PCR assay is applicable in the clinical laboratory in China.

The comparison of clinical samples in Hunan CDC showed that all of the $140 \mathrm{HIV}-1$ positive samples were quantified and 11 HIV-1 negative samples were negative with the HIV-1 quantitative RT-qPCR assay and Human Immunodeficiency Virus Type 1 (HIV-1) PCR Kit (DaAn gene, Guangzhou, China). This finding indicates that there was a $97.1 \%$ agreement rate between the two assays and that the sensitivity and specificity of the HIV-1 quantitative RT-qPCR assay were $99 \%$ and $100 \%$, respectively. Although the levels detected by the HIV-1 quantitative RT-qPCR assay for the $140 \mathrm{HIV}-1$ positive samples were slightly higher than those detected by the Human Immunodeficiency Virus Type 1 (HIV-1) PCR Kit (DaAn gene, Guangzhou, China), they showed a good correlation with the levels obtained. The mean difference was $0.39 \log _{10} \mathrm{IU} / \mathrm{ml}$.

In conclusion, the HIV-1 quantitative RT-qPCR assay showed good analytical sensitivity and reproducibility, as well as no cross-reactivity and, no interference. The coverage of HIV-1 subtypes including group $\mathrm{M}, \mathrm{N}$ and $\mathrm{O}$ of the HIV-1 quantitative RT-qPCR assay was shown by several results of this study. In particular, the LoD of HIV-1 quantitative RT-qPCR assay (33.9 IU/ml for sample vol. $0.4 \mathrm{ml}$ ) was similar with Abbott RealTime HIV-1 (68 IU/ml for sample vol. $1 \mathrm{ml}$ ) (Abbott, Des Plaines, USA) and COBAS AmpliPrep/COBAS TaqMan HIV-1 Test, Ver. 2.0, (33.4 IU/ $\mathrm{ml}$ for sample vol. $1 \mathrm{ml}$ ) (Roche Diagnostics, Branchburg,
USA) (Abbott, 2009; Roche, 2013), even though the HIV-1 quantitative RT-qPCR assay required only $0.4 \mathrm{ml}$ of sample volume. The small sample volume has an advantage for diagnostic application, especially in quantification of children samples. In addition, the HIV-1 quantitative RT-qPCR assay showed high agreement with the Human Immunodeficiency Virus Type 1 (HIV-1) PCR Kit (DaAn gene, Guangzhou, China). These findings indicate that the HIV-1 quantitative RT-qPCR assay is applicable to the quantification of HIV-1 RNA levels in the present situation, in which the high rate of global diversification of HIV-1 is expected to continue. Thus, this study provides basic data for the development of an in vitro diagnostic test for the quantification of various subtypes of HIV-1.

\section{Conflict of interest}

None.

\section{REFERENCES}

Abbott. Abbott RealTime HIV-1. Abbott. 2012.

Abecasis AB, Wensing AMJ, Paraskevis D, Vercauteren J, Kristof T, Vijver DAV, Albert J, Asjö B, Balotta C, Beshkov D, Camacho RJ, Clotet B, Gascun C, Griskevicius A, Grossman Z, Hamouda O, Horban A, Kolupajeva T, Korn K, Kostrikis LG, Kücherer C, Liitsola K, Linka M, Nielsen C, Otelea D, Paredes R, Poljak M, Puchhammer-Stöckl E, Schmit JC, Sönnerborg A, Stanekova D, Stanojevic M, Struck D, Boucher CAB, Vandamme AM. HIV-1 subtype distribution and its demographic determinants in newly diagnosed patients in Europe suggest highly compartmentalized epidemics. Retrovirology. 2013. 10: 7.

AIDSinfor. Guidelines for the use of antiretroviral agents in HIVinfected adults and adolescents. ADISinfor. 2014.

Amendola A, Bordi L, Angeletti C, Visco-Comandini U, Abbate I, Cappiello G, Budabbus MA, Eljhawi OA, Mehabresh MI, Girardi E, Antinori A, Ippolito G, Capobianchi MR. Underevaluation of HIV-1 plasma viral load by a commercially available assay in a cluster of patients infected with HIV-1 $\mathrm{A} / \mathrm{G}$ circulating recombinant form (CRF02). J Acquir Immune Defic Syndr. 2002. 31: 488-494.

Amendola A, Marsella P, Bloisi M, Forbici F, Angeletti C, Capobianchi MR. Ability of two commercially available assays 
(Abbott RealTime HIV-1 and Cobas AmpliPrep/Cobas TaqMan HIV-1 version 2.0) to quantify low HIV-1 RNA levels $(<1,000$ copies/milliliter): Comparison with clinical samples and NIBSC working reagent for nucleic aci. J Clin Microbiol. 2014. 52: 2019-2026.

Buonaguro L, Tornesello ML, Buonaguro FM. Human immunodeficiency virus type 1 subtype distribution in the worldwide epidemic: pathogenetic and therapeutic implications. J Virol. 2007. 81: 10209-10219.

Clarke JR, Galpin S, Braganza R, Ashraf A, Russell R, Churchill $\mathrm{DR}$, Weber JN, McClure MO. Comparative quantification of diverse serotypes of HIV-1 in plasma from a diverse population of patients. J Med Virol 2000. 62: 445-449.

de Mendoza C, Alcamı J, Folgueira D, Soriano V. Evaluation of the Abbott LCx quantitative assay for measurement of human immunodeficiency virus RNA in plasma. J Clin Microbiol. 2002. 40: 1518-1521.

Geelen S, Lange J, Borleffs J, Wolfs T, Weersink A, Schuurman R. Failure to detect a non-B HIV-1 subtype by the HIV-1 Amplicor Monitor test, version 1.5: a case of unexpected vertical transmission. AIDS. 2003. 17: 781-782.

Hemelaar J, Gouws E, Ghys PD, Osmanov S. Global and regional distribution of HIV-1 genetic subtypes and recombinants in 2004. AIDS. 2006. 20: W13-W23.

Holguín A, de Mendoza C, Soriano V. Comparison of three different commercial methods for measuring plasma viraemia in patients infected with Non-B HIV-1 subtypes. Eur J Clin Microbiol Infect Dis. 1999. 18: 256-259.

Jagodzinski LL, Wiggins DL, McManis JL, Emery S, Overbaugh J, Robb M, Bodrug S, Michael NL. Use of calibrated viral load standards for group $\mathrm{M}$ subtypes of human immunodeficiency virus type 1 to assess the performance of viral RNA quantitation tests. J Clin Microbiol. 2000. 38: 1247-1249.

Jung D, Lee H, Park S. Mycobacterium tuberculosis DNA detection and molecular drug susceptibility test in AFB-stained sputum slides. Biomed Sci Lett. 2016. 22: 24-28.

Korea CDC. Molecular epidemiology of HIV in Korea. KCDC. 2008. 1: 581-584.

Lee S, Wood O, Taffs RE, Hu J, Machuca A, Vallejo A, Hewlett I. Development and evaluation of HIV-1 subtype RNA panels for the standardization of HIV-1 NAT assays. J Virol Methods. 2006. 137: 287-291.

MacNeil A, Sarr AD, Sankalé JL, Meloni ST, Mboup S, Kanki P. Direct evidence of lower viral replication rates in vivo in human immunodeficiency virus type 2 (HIV-2) infection than in HIV-1 infection. J Virol. 2007. 81: 5325-5330.

Marlink R, Kanki P, Thior I, Travers K, Eisen G, Siby T, Traore I, Hsieh CC, Dia MC, Gueye EH. Reduced rate of disease development after HIV-2 infection as compared to HIV-1. Science. 1994. 265: 1587-1590.

Marlink RG, Ricard D, M'Boup S, Kanki PJ, Romet-Lemonne JL, N'Doye I, Diop K, Simpson M, Greco F, Chou MJ. Clinical, hematologic, and immunologic cross-sectional evaluation of individuals exposed to human immunodeficiency virus type-2 (HIV-2). AIDS Res Hum Retroviruses. 1988. 4: 137-148.

Michael NL, Herman SA, Kwok S, Dreyer K, Wang J, Christopherson C, Spadoro JP, Young KKY, Polonis V, McCutchan FE, Carr J, Mascola JR, Jagodzinski LL, Robb ML. Development of calibrated viral load standards for group $M$ subtypes of human immunodeficiency virus type 1 and performance of an improved AMPLICOR HIV-1 MONITOR test with isolates of diverse subtypes. J Clin Microbiol. 1999. 37: $2557-2563$.

Moss JA. HIV/AIDS Review. Radiol Technol. 2013. 84: 247-267.

Oh IY, Kim KT, Jun JH, Shin J-H, Sung HJ. Development of realtime PCR assays for detection of Dirofilaria immitis from infected dog blood. Korean J Clin Lab Sci. 2016. 48: 88-93.

Osmanov S, Pattou C, Walker N, Schwardländer B, Esparza J, WHO-UNAIDS Network for HIV Isolation and Characterization. Estimated global distribution and regional spread of HIV-1 genetic subtypes in the year 2000. J Acquir Immune Defic Syndr 2002. 29: 184-190.

Park M-S, Cho H-W, Kim J-G, Bae N-Y, Oh D-S, Park H-H. Genotype analysis of human papilloma virus infection in accordance with cytological diagnoses. Korean J Clin Lab Sci. 2015. 47: 39-45.

Plantier J-C, Leoz M, Dickerson JE, Jonathan E, Oliveira F, Cordonnier F, Lemée V, Damond F, Robertson DL, Simon F. A new human immunodeficiency virus derived from gorillas. Nat Med. 2009. 15: 871-872.

Qiagen. artus HI Virus-1 QS-RGQ performance characterics. Qiagen. 2012

Reeves JD, Doms RW. Human immunodeficiency virus type 2. J Gen Virol. 2002. 83: 1253-1265.

Roche. COBAS AmpliPrep/COBAS TanMan HIV-1 Test-Ver.2. Roche. 2013.

Shin HI, Kim IC, Cho TJ. Replication and encapsidation of recombinant turnip yellow mosaic virus RNA. BMB Rep. 2008. 41 739-744.

Swanson P, de Mendoza C, Joshi Y, Golden A, Hodinka RL, Soriano 
V, Devare SG, Hackett J. Impact of human immunodeficiency virus type 1 (HIV-1) genetic diversity on performance of four commercial viral load assays: LCx HIV RNA quantitative, AMPLICOR HIV-1 MONITOR v1.5, VERSANT HIV-1 RNA 3.0, and NucliSens HIV-1 QT. J Clin Microbiol. 2005. 43: 3860-3868.

Swanson P, Harris BJ, Holzmayer V, Devare SG, Schochetman G, Hackett Jr. J. Quantification of HIV-1 group M (subtypes A-G) and group $\mathrm{O}$ by the LCx HIV RNA quantitative assay. J Virol Methods. 2000. 89: 97-108.

Takebe Y, Kusagawa S, Motomura K. Molecular epidemiology of
HIV: Tracking AIDS pandemic. Pediatr Int. 2004. 46: 236-244. Taylor BS, Hammer SM. The challenge of HIV-1 subtype diversity. N Engl J Med. 2008. 359: 1965-1966.

Triques K, Coste J, Perret JL, Segarra C, Mpoudi E, Reynes J, Delaporte E, Butcher A, Dreyer K, Herman S, Spadoro J, Peeters M. Efficiencies of four versions of the AMPLICOR HIV-1 MONITOR Test for quantification of different subtypes of human immunodeficiency virus type 1. J Clin Microbiol. 1999. 37: 110-116.

Weiss RA. How does HIV cause AIDS? Science. 1993. 260: 1273 -1279 . 